\title{
International Harmonisation
}

\author{
Of Accounting Standards: \\ The Case For A Mandatory Requirement \\ For The Direct Method Of \\ Reporting Operating Cash Flows \\ Christine Yap (E-mail: cmcly@cc.newcastle.edu.au), The University of Newcastle, Australia
}

\begin{abstract}
Even though standard setters have now embraced cash flow statements there remains ambivalence as to the best format (i.e. direct or indirect method) for disclosing cash flow from operations. In 1987 the FASB asserted that information about the gross amounts of cash receipts and cash payments is more relevant than information about the net amounts of cash receipts and payments. Yet apart from Australia and New Zealand, most standard setting bodies, including the International Accounting Standards Board (IASB), permit a choice between the direct and indirect methods. When given this choice, the vast majority of companies have opted for the indirect method of reporting operating cash flows (OCFs).

This difference in OCF presentation between jurisdictions is relevant in this era of harmonisation of accounting standards: both the European Union parliament and the Australian Financial Reporting Council have decided to set 2005 as the target date for the adoption of standards produced by the IASB. Underlying this policy of verbatim adoption of international accounting standards, presumably is the belief that adoption of standards issued by the IASB would lead to an improvement in financial reporting. Such a view was presented recently when current Australian accounting standards were criticised as being "deplorable" by the Chairman of the IASB, David Tweedie (Australian Financial Review, 5 August 2003, p.1). Yet by reviewing the literature on cash flow statements, this paper argues that not all Australian standards would be improved by adopting international standards. In the case of cash flow reporting, maybe the IASB should review its standard and accept the lead of Australia and New Zealand, by not permitting choice of method and mandate the direct method: surely an intended consequence of harmonisation is to narrow areas of difference and variety in accounting practice.
\end{abstract}

\section{Introduction}

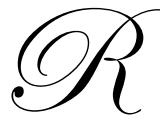

ecognition of the importance of cash flow information occurred formally in the 1980's when rules for the inclusion of cash flow statements in annual reports began to be incorporated into accounting standards. Cash flow statement (CFS) standards were issued by five national standard-setting bodies (Australia, Canada, New Zealand, the United Kingdom and the United States) and the International Accounting Standards Committee (IASC) ${ }^{1}$ within a relatively short period of time $(1985-1992)^{2}$. "Cash flow reporting is one of the few

\footnotetext{
1 The IASC (now the International Accounting Standards Board or IASB) has neither international nor national regulatory mandate for setting accounting standards (Wallace, 1991). Nevertheless its standards have been endorsed as national standards in many countries such as Hong Kong, Malaysia and Singapore.

2 The cash flow statement (CFS) requirement replaced the statement of changes in financial position (funds statement).
} 
significant changes in the financial accounting practices of recent times" (Lee, 1993, p.ix). Yet, even though accounting regulators have clearly embraced CFSs, there remains ambivalence as to the best format for disclosing cash flow from operations (i.e. direct or indirect method).

In 1987 the FASB asserted that information about the gross amounts of cash receipts and cash payments (as shown by the direct method) is more relevant than information about the net amounts of cash receipts and payments (FASB, 1987, para.11). Despite this assertion, most standard setting bodies (apart from Australia and New Zealand), permit a choice between the direct and indirect methods. Such choice allows differences to continue between reporting jurisdictions. However, the increasing internationalisation of capital markets over recent years has greatly increased the pressure for uniformity of accounting rules worldwide: convergence of accounting standards is now one of the prime objectives of standard setters. This paper, by reviewing the cash flow literature, looks at the relative merits of the two methods of reporting operating cash flows. It provides support for the view that all standardsetters, particularly the IASB, should make the direct method mandatory.

\subsection{Importance Of CFS Format}

CFS standards generally recommend that CFs be categorised into three activity types: operating, financing and investing cash flows ${ }^{3}$. Standard setters presumably believe that such categorisation enhances comparability and the evaluation of relationships among these categories. Presumably classified CFs would be more helpful to users.

Classification in financial statements facilitates analysis by grouping items with essentially similar characteristics and separating items with essentially different characteristics. Analysis aimed at objectives such as predicting amounts, timing, and uncertainty of future cash flows requires financial information segregated into reasonably homogeneous groups. (FASB, 1984, para.20)

Within the operating activities classification, regulatory authorities have identified two methods of presenting cash flow information: direct and indirect. Both methods, whilst resulting in the same figure for net operating cash flows, have significant differences. The direct method reports in a straight-forward manner how much cash and cash equivalents came in from customer collections and how much went out in the form of payments to suppliers, employees, and other outside entities for goods and services. The direct method approximates a summarised cash book. The indirect method does not follow the trading or operational sequence but instead arrives at the net cash flow from operations by working backwards from net profit. Net profit or loss is adjusted for (1) the effect of non-cash revenue and expenses (eg. depreciation) and changes in non-cash working capital, (2) any cash receipts and payments unrelated to the reporting year and (3) items associated with investing and financing activities that were incorporated in the profit or loss figure.

Given these two methods, there are three options open to a regulatory authority for presenting operating cash flows (OCFs): (1) to mandate the direct method only, with or without the need to reconcile the net cash flow from operations with the net profit figure; (2) to permit choice, namely the use of either the direct (with or without reconciliation) or the indirect method; or (3) to mandate the indirect method, with or without direct method proof of operating cash flow.

The Australian and New Zealand standards mandate the direct method with reconciliation, whereas other regulators allow a choice between the direct and indirect methods provided they adhere to the consistency principle of not changing that choice without providing a reason for the change ${ }^{4}$. This difference in OCF presentation between jurisdictions is relevant in this era of harmonisation of accounting standards: both the European Union parliament and the Australian Financial Reporting Council have decided to set 1 January, 2005 as the target date for the adoption of standards produced by the IASB. Underlying this policy of verbatim adoption of international

3 Cash flows from operating activities show the results of cash inflows and outflows related to the fundamental operations of the basic line (or lines) of business in which the company operates; cash flows from investing activities show the CFs associated with purchases and sales of non-current assets; cash flows from financing are the flows related to the financing of the other activities of the firm.

4 Although SFAS 95 and IAS 7 permit the indirect method, they cite the direct method as the preferred method of presenting OCFs (FASB, 1987, para. 27; IASC, 1992, para.19). 
accounting standards, presumably is the belief that adoption of standards issued by the IASB would lead to an improvement in financial reporting and the efficiency of the capital markets. However, in the case of Australia, as the international standard on cash flow statements (IAS 7) differs from its Australian counterpart (AASB 1026) by allowing operating cash flows to be presented by the direct or indirect method ${ }^{5}$, it could be argued that the Australian CF standard (which mandates the direct method) is in fact preferable to IAS $7^{6}$. Recently some Australian accounting standards have been criticised as being "deplorable" by the Chairman of the IASB, David Tweedie (Australian Financial Review, 5 August 2003, p.1) . $^{7}$. Yet, at least in the case of cash flow reporting, maybe the IASB should review its standard and accept the lead of the Australian standard setter, by not permitting choice of method: surely an intended consequence of harmonisation is to narrow areas of difference and variety of accounting practice.

The internationalisation of the Australian CFS standard began in May, 2003, when the Australian Accounting Standards Board issued Exposure Draft 110, Request for Comment on IAS 7 Cash Flow Statements. ED 110 reproduces IAS 7 verbatim, but in the preface proposes amendments which essentially retain the features of the current CFS standard. For example, "The Board is of the view that the Australian equivalent of IAS 7 should present the cash flow statement using the direct method" (AASB, 2003, p. 10). It goes on to explain "that a standard that permits only one of the two options allowed in an IFRS ${ }^{8}$ is fully compliant with that IFRS" (AASB, 2003, p.11). The AASB's preference for the current Australian CF standard suggests that it believes that it is quite acceptable for the Australian versions of IFRSs to be more restrictive than the equivalent IFRSs. In other cases, it has been flagged that Australia will be pleading certain exemptions from IFRSs in areas such as intangibles and derivatives ${ }^{9}$ - surely such proposals defeat the objective of adopting IFRSs, which presumably is to internationalise Australia's capital markets.

The remainder of this paper is organised as follows: section two provides a comparison between the direct and indirect methods; section three reviews submissions to regulatory authorities on OCFs; section four reveals reporting practice when choice is permitted; and the final section concludes the case for the direct method.

\section{Comparison Of The Direct And Indirect Methods}

There is a need to provide evidence on the validity of the FASB's assertion that information about the gross amounts of cash receipts and cash payments is more relevant than information about the net amounts of cash receipts and payments (FASB, 1987, par.11). If the direct method is found to be superior to the indirect method than all standard setting bodies should consider mandating the direct method, particularly since the FASB is concerned about costs and benefits of accounting standards. The FASB states (1980a, par.133-140) that from society's perspective, such costs should be minimised where possible. If users not receiving direct OCF information incur additional costs, first in estimating and collecting that information, and second, in potentially misallocating resources when basing decisions on incomplete information, then the direct format should be mandated since firms are the least cost producers of information about themselves.

The following literature review allows an examination of the relative merits of the two methods:

\footnotetext{
5 A number of items are dealt with in more detail in AASB 1026 than in IASB GAAP (AASB, 2002):

"AASB 1026 (paragraph 6.1) requires cash flows arising from operating activities to be presented in the statement of cash flows using the direct method, whereby each major class of gross cash receipts and gross cash payments is disclosed. In contrast IAS 7.18 allows the reporting of cash flows from operating activities using either the direct method or the indirect method "(AASB, 2002, p.21). IAS7 does not require a reconciliation where the direct method has been used.

6 Australian financial statement users receive the benefits of both direct and indirect OCF information (indirect OCFs are shown in the notes). However the majority of users in other jurisdictions only receive indirect OCFs.

7 David Tweedie's comments were mostly directed at Australia's treatment of intangibles and derivatives.

8 International financial reporting standard.

9 For example the AASB has pressed the IASB for certain concessions on the implementation of new intangible rules (Australian Financial Review, 5 August, 2003, p.6).
} 


\subsection{Advantages Of The Direct Method Noted In The Literature}

- Disclosure of actual sources and uses of cash: In terms of the provision of relevant information to users, the literature indicates that the direct method is greatly superior to the indirect method because it focuses on disclosure of gross cash flows; reports movements in the individual components of $\mathrm{CF}$ items; and emphasises the disaggregation ${ }^{10}$ of $\mathrm{CF}$ from operating, investing and financing activities.

This information on gross cash flows can be used to:

$\circ \quad$ Evaluate operating efficiency by reviewing individual $\mathrm{CF}$ items for analytic significance. For example, the trend of, and interrelationships between, different CF components over time and their relationship to related profit and loss statement items can be examined (White et al, 1998) ${ }^{11}$. Compare similar types of cash receipts and payments across firms (Richardson, 1991). The subjectivity of accrual accounting can mean that companies in the same industry with similar economic activities can report different profit patterns only because their accounting methods and assumptions differ. "The cash flow statement allows the analyst to distinguish between the actual events that have occurred and the accounting assumptions that have been used to report these events" (White et al, 1998, p.108). The CFS using the direct method shows the extent to which cash collected, cash disbursed, and CFO are similar between companies despite very different profit figures.

- Make credit decisions and assess a company's ability to service existing debt. The direct method was actively supported by Robert Morris Associates (who represent the interest of commercial lenders in the US) during the standard-setting process in the lead-up to the development of a CFS (Cornell and Apostolou, 1992).

- $\quad$ Facilitate comparison of actual cash flows with budget (Trout $e t$ al, 1993).

- Assist in conducting sensitivity analyses of CFs to volume changes (Cornell and Apostolou, 1992).

- $\quad$ Direct presentation of OCFs is consistent with the format used for investing and financing cash flows (i.e. gross cash inflows and outflows are disclosed)

- Understandability: It presents an entity's OCFs in a manner that is clear and understandable to nonsophisticated users of accounting information (O’Leary, 1988). Someone without a technical background in accounting can easily tell where cash came from and where it went during the period. Clearly this is an important advantage given that understandability is an important characteristic of accounting information (FASB, 1980a).

- $\quad$ Consistency with CFS objective: If the objective of the CFS is to provide information about gross cash inflows and outflows, the indirect method fails, as it reports nothing about individual operating cash receipts or payments ${ }^{12}$.

- $\quad$ Forecasting future cash flows: According to the UK standard, FRS 1 (ASB, 1991, para.70) and the Australian standard (AASB 1026, 1991b) the direct method also assists in forecasting future cash flows ${ }^{13}$.

\footnotetext{
${ }^{10}$ Disaggregation of earnings has been shown to improve profitability forecasts (Fairfield et al, 1996). Hence there is the possibility that cash flow disaggregation may also improve forecasting.

${ }^{11}$ For example, a comparison of revenue and expense trends with the pattern of cash collections from customers and cash payments should reveal the causes of lower CFO and suggest whether the trend is likely to reverse. "Direct method statements allow analysts to make such comparisons because they provide information better suited to analysis. Direct method statements reveal, for example, whether CFO is increasing because cash collections are increasing or payments to suppliers are decreasing" (White et al, 1998, p.111).

${ }^{12}$ SFAS 95 "...the direct method is more consistent with the objective of a statement of cash flows - to provide information about cash receipts and cash payments - than the indirect method, which does not report operating cash receipts and payments." (FASB, 1987, para. 111)

13 "This [direct] method provides information that is not otherwise available in the balance sheet and profit and loss account. It provides a more useful basis for estimating future cash flows than a method of presentation which discloses only the net amount of cash flows from operating activities and does not report the individual components of cash flows from operating activities" (AASB 1026, 1991b, Commentary p. xxvi).
} 
The predictive ability of the CFS is not subject to the same implicit assumptions (such as going concern) as statements prepared using accrual accounting. When the going concern assumption is subject to doubt, revenue recognition and asset valuation (particularly for intangibles) can no longer be taken for granted: the value of items such as inventory and receivables decline sharply when they must be quickly liquidated. In this respect, the statement of cash flows serves as a 'check' on the assumptions inherent in the profit and loss statement (White et al., 1998).

To find out why income can fail as a predictor of cash-generating ability (uncollected receivables or unsold inventories) requires a comparison of amounts recorded as sales and cost of goods sold on the income statement with the pattern of cash collections from customers and cash paid for inventories on the cash flow statement. A direct method cash flow statement is helpful in this regard. (White et al, 1998, p.108)

- $\quad$ Ratio Analysis: Some ratios can only be generated by using amounts disclosed by the direct method (such as those used to judge quality of sales; i.e. comparing cash from customers to sales revenue).

- $\quad$ Predict Insolvency: A model which uses both net and gross CF information can be used to predict financial distress (Ward, 1995). Because the model requires gross OCFs Ward suggests "that the FASB should have required companies to use the direct method to calculate CF from operating activities" (1995, p.29).

\subsection{Disadvantages Of The Direct Method Noted In The Literature}

- $\quad$ Too revealing: Some companies believe the direct method reveals too much about their business to their competitors.

- $\quad$ Cost: The Accounting Standards Board, while acknowledging the advantages of the direct method, nevertheless stated that it "does not believe at present that in all cases the benefits to users of this information outweigh the costs to the reporting entity of providing it and, therefore, has not required the information to be given" (ASB, 1991, para. 70).

This argument is not persuasive: cost should not be significant, particularly since most firms nowadays would be computerised. In any case, the direct method doesn't require developing separate cash-based systems to capture all operating cash receipts and payments; rather companies may derive direct-method amounts by adjusting profit and loss statement items for changes in related balance sheet items.

\subsection{Advantages Of The Indirect Method Noted In The Literature}

A search of the literature does not provide many advocates for the indirect method. Most of the following arguments in favour of the indirect method are readily disputed by direct method proponents.

- $\quad$ Explains differences between net profit and operating cash flows: Advocates of the indirect method argue that it is more informative than the direct method because it (1) emphasises the build-up (liquidation) of working capital (receivables, payables, inventories, etc.), thereby explaining the difference between net profit and operating cash flow ${ }^{14}$ and (2) keeps management honest, i.e., it reduces the ability of management to manipulate the profit and loss statement without notice by report users ${ }^{15}$ (Wallace et al, 1997).

\footnotetext{
${ }^{14}$ Jamieson (1995) criticises the direct method of reporting CFO claiming that "cash tied up in working capital in the form of debtors, stocks and creditors is not revealed. This is a serious defect as it is lack of control over working capital that has led to many a company crash" (p.44).

15 FRS 1 para.71: "The principal advantage of the indirect method is that it highlights the differences between operating profit and net cashflow from operating activities. Many users of financial statements believe that such a reconciliation is essential to give an indication of the quality of the reporting entity's earnings" (ASB, 1991).
} 
The indirect method, by articulating the CFS with the balance sheet and profit and loss statement, is more of an arithmetic proof of net operating profit than it is a statement of cash flows (Seed, 1984; Thompson and Buttross, 1988). Such a focus on the differences between profit on an accrual basis and a cash basis is certainly useful in emphasising the differences between cash and accrual accounting, but it still can be shown, as a note, when the direct method is used. When a company uses the direct method, most standards also require a reconciliation to be shown as a note to the CFS. Effectively both the direct and indirect methods are reported, thus capturing the advantages of both.

- $\quad$ Estimating future cash flows: FRS 1, identifies the information provided by the reconciliation between operating profit and OCFs as being useful: "Some investors and creditors assess future cashflows by estimating future income and then allowing for accruals adjustments; thus information about past accruals adjustments may be useful to help estimate future adjustments" (para.71). However, Sorter (1982) disputes this view: "If users of financial reporting are interested in predicting cash flows, they are interested in assessing changes that produce a cash impact not in those that do not. The add-back method which focuses on events, such as depreciation, that do not have cash impacts is not useful for this purpose and should not be utilised" (p.193).

- Less costly: A more pragmatic reason for preferring the indirect method is provided by Harvey (1991). He points out that many companies do not have accounting systems that are suitable to the preparation of the direct method of OCFs thereby making the direct method costly. ${ }^{16}$ Given the developments in accounting systems since 1991, such an argument would probably no longer be relevant.

Knutson (1993) disputes the cost argument as follows: costs of preparing financial statements "are paid out of general corporate funds and, ultimately, are borne by the firm's investors-that is, the users of financial statements. If financial statement users demand information in a particular form, then it should be provided. If the costs of providing such information truly are prohibitive, the demand will cease as investors refuse to absorb the concomitant decrease in the value of the securities they hold" (p.66-67).

- Information on actual cash flows can be generated by users themselves: It is claimed that users can estimate the various components of OCFs by starting with the profit and loss statement and reversing accruals associated with each item in the statement. This is debatable as there is seldom sufficient detail given in published financial statements of the individual reconciling items to make the adjustments suggested: it is necessary to make assumptions about the accruals and their relationships with profit and loss statement numbers. For example, the amount shown in accounts receivable may represent receivables from various activities entered into by the company. Not all of these activities are necessarily related to the sales of the firm. As Knutson (1993) explains:

If the reconciling items "can easily be evaluated by an analyst," they can even more easily (and accurately) be evaluated by the reporting enterprise. Not only that, but evaluation and adjustment, if done by the reporting enterprise, need to be done only once, thus saving the greater efforts of and lesser accomplishments by the scores if individual analysts who may follow the firm. (p.66)

Drtina and Largay (1985) claim that the indirect method, at best, produces an estimate of CFO which differs from actual CFO by an unknown amount. They identify a number of problems which arise from the use of the indirect method, such as 'ambiguity in the definition of operations', which "contaminate the data used in research studies employing the indirect method" (p.325). This was confirmed by the Bahnson et al (1996) study which showed that there are many unexplained differences between reported operating cash flow figures and expected measures. Approximately 75 per cent of their sample of over 9,700 companies presented nonarticulated changes in current accounts. This result was supported by a UK study (Wallace $e t$ al, 1999, p.317).

\footnotetext{
${ }^{16}$ Anecdotal reports suggest that this has not been the case in Australia and New Zealand, which have successfully mandated the direct method: firms have not installed new systems but derive their CF information from numbers generated by current accrual systems (Wallace, 1999, p.341).
} 
- $\quad$ Financial statement users are more familiar with: In a survey of CPAs, those who preferred the indirect method justified their view as habit and consistency with past practice (Gibson et al, 1986) ${ }^{17}$. This view was also put forward by Mahoney et al, 1988.

\subsection{Disadvantages Of Indirect Method Noted In The Literature}

- $\quad$ Confusing: The indirect method, by combining accrual accounting transactions with cash and noncash adjustments, makes the CFS confusing to use and the analysis of the cash cycle more difficult. It uses many of the same account titles found in other financial statements, which could confuse some CFS users ${ }^{18}$. For example, the OCF section prepared using the indirect method begins with 'operating profit' and 'depreciation'. Both of these line titles are in the profit and loss statement. Depreciation is added back to operating profit on the CFS, whereas it is a deduction in the profit and loss statement (Smith and Freeman, 1996).

The indirect method is overly complicated with a seemingly random arrangement of increases and decreases in current assets and current liabilities. In contrast, the direct method presents all increases in cash first and then follows with the decreases in cash, resulting in a much more straightforward presentation.

- $\quad$ Provides little new information: The indirect method provides little more than a reconciliation statement readily derivable from the balance sheet and profit and loss statement ${ }^{19}$ (Lee, 1983). As White et al (1998) explain, OCFs prepared using the indirect method have a significant drawback:

Because of the indirect format, it is not possible to compare operating cash inflows and outflows by function with the revenue and expense activities that generated them, as it is possible from cash flow statements prepared using the direct method. In the absence of acquisitions, divestitures, and significant foreign operations, the indirect method simply recasts the income statement and the balance sheet, providing little new information on or insight into a firm's cash-generating ability. (White et al, 1998, p.90)

\subsection{Summary}

Direct method advocates do not argue that no reconciliation should be provided; rather that a reconciliation is not a substitute for reporting actual cash flows. And given that some CFS standards require that a reconciliation of net profit to net CFO be displayed regardless of the method employed (for example, SFAS 95), the direct method provides all the information presented by the indirect method plus the itemisation of gross operating receipts and payments $^{20}$. In addition, the relevance of the CFS (prepared under the direct method) to a variety of decision contexts, including liquidity and solvency evaluation, monitoring and prediction assessments, performance evaluation, calculation of free CF and valuation models, has been supported in several studies (see Neill et al, 1991, Lee, 1981a, 1981b, 1993; McEnroe, 1989; Jones et al, 1995; White et al, 1998). Hence, there does not appear to be a

\footnotetext{
17 "Lack of contact with or training in the direct method, plus pure habit, may have caused the responding accountants to not judge the direct method fairly" (Gibson et al, 1986, p.35). They found $75 \%$ of CPAs preferred the indirect method - probably a reflection of the time the study was undertaken, namely before the mandatory CFS standard.

18 "The indirect method of calculating cash provided by operations is pernicious because it is almost certain to continue to confuse financial statement users by reinforcing the incredible belief that profits and depreciation are sources of cash. The direct method, on the other hand, is likely to be useful in dispelling some of the confusion that now exists over the relationship between business activities and cash receipts and payments because it shows clearly that profits are neither cash nor a source of cash, that cash comes from customers, that it is paid for merchandise, administrative and selling expenses, taxes and so forth and that depreciation is neither a source nor a use of cash" (Heath, 1978, p.99).

19 Heath (1978) suggested that the direct method of presenting CFO be used because it "shows the actual sources and uses of cash... The indirect method is basically a set of worksheet adjustments rather than an explanation of how operating activities affected cash. It is analogous to calculating income by subtracting stockholders' equity at the beginning of the year from stockholders' equity at the end of the year and then adjusting the difference for nonincome items, such as dividends and purchases and sales of capital stock." (p.99)

${ }^{20}$ Major classes of gross cash flows from investing and financing activities are required to be reported irrespective of the method used to disclose OCFs.
} 
conceptual reason why the indirect method is permitted: "Not only does it 'hide' all those individual elements of cashflow which contribute to the net cashflow from operating activities, but it also combines working capital adjustments and cashflow details" (Jones, 1990, p.31). This would hamper understandability, one of the oft-quoted advantages of cash flow information.

Bahnson et al (1996) suggest that mandating the direct approach "should lead to more efficient pricing of capital by providing new public information about gross operating cash inflows and outflows, by reducing users' processing costs, and by reducing the risk penalty for the uncertainty associated with the user-generated estimates of gross operating inflows and outflows.” (p. 11)

\subsection{User Perception Studies}

Surveys of Australian preparers and users have found substantial support for the Australian standard, AASB1026 Statement of Cash Flows. Jones et al (1995) found overwhelming support by Australian companies for the requirements of $A A S B 1026$, including such requirements as the direct method of reporting cash flows ${ }^{21}$. These authors also found that their preparer respondents perceived the CFS to have a high degree of decision usefulness, particularly to bankers, managers and institutional investors. This perception was confirmed by a survey of financial statement users in the Australian finance sector (Yap, 1997). Hung et al (1995) also found that the majority of users from Hong Kong prefer the direct method of presenting OCFs.

Jones et al (1997) reported that firms displayed strong support for direct method reporting of OCFs:

...while the direct method was considered more complex, costly and time consuming, the method was perceived by these firms to: help users understand cash-flow data; facilitate cash-flow analysis; reflect accepted commercial practice; and have a sounder conceptual basis. These results imply that the direct method is perceived by respondents to satisfy the information requirements of diverse potential users. (Jones et al, 1997, p.77)

These Australian survey results have been confirmed elsewhere. For example, Robert Morris and Associates, who represent more than 15,000 bank loan and credit officers in the United States, has adamantly advocated the direct method (Cornell and Apostolou, 1992; Knutson, 1993). A survey of governmental finance officers in the United States revealed that almost $75 \%$ of respondents selected either the direct method only or the direct method with reconciliation as the preferred CFS format (Smith and Freeman, 1996).

\subsection{Other Empirical Studies}

When used in conjunction with other financial statements both CF statement formats appear to contain similar information. However as Bahnson et al (1996) have shown, the direct cash flows cannot be easily ascertained from the indirect format. Hence the retrieval and processing of direct CFs may not be uniform, or indeed accurate, because different formats may alter the complexity of presentation. This finding was confirmed by Krishnan and Largay (2000) when investigating the predictive ability of the direct method of CF information. They found: (1) superior relative ability of past period direct method $\mathrm{CF}$ data over indirect method $\mathrm{CF}$ data to predict future operating $\mathrm{CFs}$; (2) that measurement error exists when estimating direct method operating CFs indirectly from other financial information, with measurement error generally significant in estimates of cash paid to suppliers and employees; and (3) greater relative ability of past operating CFs to predict future operating CFs over earnings and other accrual information. However they note that predictions are better when past operating CFs, and earnings and accrual information, are used together. They concluded that financial statement users not privy to direct method CFs are at disadvantage to those who have access to that information.

An early study, using pre-SFAS 95 data, by Gahlon and Vigeland (1988), examined the CF differences between failed and non-failed firms. They estimated CFs using the direct method, finding them to be significant in discriminating between bankrupt and non-bankrupt industrial firms as much as five years prior to bankruptcy. They concluded "An

\footnotetext{
${ }^{21}$ Specifically CFO (derived by the direct method) "rated as the most important cash flow measure by respondents". In addition, "crude measures of cash flow... which are readily derived under the indirect method, received the lowest ratings of importance...(Jones et al, 1995)"
} 
indirect cash flow statement will not provide a number of the cash flow variables for which we found significant differences... Thus, using an indirect cash flow statement could lead to ignoring important information about credit worthiness." (p.14)

The usefulness of the direct method was further confirmed in an experimental study which examined the impact of the format of CF presentation on decision making. Klammer and Reed (1990) found that American bank loan officers' supplied with the direct method of CFO were more accurate in their answers to computational questions and displayed greater consensus in a loan decision than those bank loan officers given the indirect format. In addition, Pratt and Chrisman (1982) when comparing the effects of the direct and indirect methods of teaching the funds statement (the forerunner to the CFS), found that students exposed to the direct method scored higher on objective exam questions and perceived greater levels of understanding, than students receiving the indirect method.

\section{Submissions To Regulatory Authorities}

A review of letters of comment on three exposure drafts (each of which preceded the final CFS standard) reveals differing levels of support for the direct method.

\subsection{The United States Of America}

In July 1986 the FASB issued an exposure draft (ED 23) entitled Statement of Cash Flows. This exposure draft was formalised in Statement of Financial Accounting Standard No.95, Statement of Cash Flows (SFAS 95) in November 1987. The standard (which allowed choice of method) was passed by a 4-3 vote by the FASB Board. Two Board members were strongly opposed to the decision, believing that by permitting continued use of the indirect method, the Board missed an opportunity "to make a significant contribution to the quality of financial reporting and to enhance user understanding of CFs from operating activities" (FASB, 1987, p.11).

The majority of respondents to the US exposure draft argued for the direct method. These were mainly lenders, who said that gross operating cash flows were particularly important to assess borrowing needs and repayment ability. For example, many bankers put forward strong arguments in favour of the direct method:

Bank lenders focus primarily on cash flows from operating activities because the dynamics of these flows define both borrowing needs and the ability to repay. Earnings are important to bankers, but an entity's economic performance speaks to its general credit worthiness rather than to the magnitude of its borrowing needs or the availability of cash to meet debt service obligations as scheduled. The dynamics of these intermittent cash surpluses and deficits are what bankers must judge. (NCNB Corporation)

However the preparer respondents raised the 'oft-used' objection to more disclosure: namely cost. For example, Campbell Soup Company submitted that the information needed by the direct method "is not readily available to Campbell's... and would not be a cost effective solution to our cash flows statement presentation". Possibly to appease these concerns over cost, the standard, when issued, allowed choice of method.

\subsection{The United Kingdom And The Republic Of Ireland}

In July 1990, ED 54, Cashflow Statements, was issued (ASSC). The preface to $E D 54$ specifically asked for responses to a number of questions including a comment on the method of disclosure for OCFs. ${ }^{22}$. ED 54 was followed, in 1991, by the issue of Financial Reporting Standard No. 1, Cashflow Statements (ASB, FRS 1).

Respondents to $E D 54$ (U.K.) mostly opposed the direct method ${ }^{23}$ stating that it would be costly to implement as they did not currently collect information in such a form from their accounting system. For example, a respondent from industry stated:

\footnotetext{
22 "In the light of the discussion of the benefits of using the direct or the indirect method of cash flow reporting, do commentators consider that preparers should be allowed to choose which method to use, or should the statement require or prefer one or other method?" (Preface, ASSC, ED54)
} 
The practical problems involved in using the direct method in a large group are immense. There are two possible ways of arriving at the information required:

- The information flowing from the nominal ledgers can be adjusted for accruals to bring it back to a cash basis, or

- $\quad$ The cash books can be analysed in detail to obtain the necessary information.

Both ways of implementing the direct method entail a great deal of additional work and cost. The first is in fact only an approximation to the direct method and the detail provided will not be exact, but will give a 'spurious accuracy'. The second method involves detailed cash analyses and consolidation - the detail involved in analysing payments to suppliers to ascertain the cash payments for capital expenditure, for example, can be formidable (Delta Plc.).

Presumably in response to such opposition to the direct method, FRS 1 allowed a choice of method for reporting OCFs, but it encouraged firms to use the direct method if it would be cost effective:

...reporting entities must give the information required by the indirect method, but may also give the information required by the direct method and the Board encourages reporting entities to give a breakdown of their cash flows under the direct method in those circumstances where the benefits to users of the information outweigh the costs of providing it. (ASB, 1991, FRS 1, p.49).

\subsection{Australia}

In 1991 ED52, Statement of Cash Flows (AASB) was issued, specifically requesting respondent opinion on the direct method of disclosing CFO and the need for a reconciliation between CFO and profit after tax. Surprisingly a majority ${ }^{24}$ of respondents supported the mandating of the direct method despite the fact that both SFAS95 and ED54 allowed a choice of methods ${ }^{25}$. The following comments are representative of the views of supporters of the direct method:

We believe the use of the direct method will enhance user understanding of cash flows from operating activities and will better achieve the objective of financial reporting. The prescribed use of the direct method may marginally increase the cost of financial reporting, particularly in the initial year; however in our opinion it is a relatively small price to pay to improve the quality of reporting. (Esso Australia Ltd.)

Santos supports the proposed requirement to adopt the direct method as it provides the user with more detail on cash flows from operating activities than that as reported using the indirect method. The indirect method of reporting cash flows provides little more detail than could now be obtained from the current Statement of Sources and Applications of Funds. The accounting procedures needed to present information under the direct method maybe somewhat more arduous than under the indirect method but there are significant benefits to the users. (Santos Ltd.)

However seven respondents (out of 58) did prefer that a choice of methods be allowed. For example:

While the direct method of reporting cash flows from operations is acceptable, the standard should allow the indirect method to be used as an alternative. The direct method of reporting may impose significant additional costs in gathering accurate information for what is of questionable added value to the user. (ICI Australia Operations)

Supporters of the direct method also supported the presentation of a reconciliation of CFO and profit after tax as a note to the CFS:

${ }^{23}$ Of those respondents to ED54 who indicated a clear preference, only $34 \%$ favoured the direct method.

${ }^{24}$ Of those respondents to ED52 who indicated a clear preference, $78 \%$ favoured the direct method.

${ }^{25}$ New Zealand too, received overwhelming support for the direct method: In 1991 the New Zealand Society of Accountants reviewed their accounting standard on cash flow reporting, SSAP-10 and found that 47 respondents favoured a continuation of the direct method. Only 6 respondents were against the direct method. 
This information is essential to users of financial statements as it reflects the various leads and lags between cash flows and income/expense. For most preparers of cash flow statements this requirement will not be a significant additional cost burden particularly where cash flows are calculated by adjusting sales, cost of sales and other items in the profit and loss for non-cash items or items relating to financing or investing activities. (Santos Ltd.)

One of the opponents of the direct method explained their position as follows:

...we believe any gross cash flow is a meaningless reportable number. We prefer the indirect method as we believe that the focus should be on the net cash flow generated in any business, rather than the gross inflows or outflows. This view is supported by the analogy that the value of a business is based on the surplus of the net of the inflows less the outflows rather than the gross inflows alone...If the indirect method is used, the operating profit and extraordinary items after tax is the first number of the cash flow from operating activity, which the reader will be able to agree to the profit and loss account. The reconciliation required by Paragraph 36 would then be a part of the Cash Flow Statement providing the reader with a clear linkage to the operating result. (Coles Myer Ltd.)

Possibly because the supporters of the indirect method were so few in number, the Australian standard, $A A S B$ 1026, opted to mandate the direct method of reporting OCFs.

\subsection{Summary}

Despite the persuasive arguments in the literature (noted earlier) in favour of the direct method, the decision by some standard-setters to allow choice ${ }^{26}$ would appear to be a pragmatic response to the respondent views rather than a normative response: "With a normative approach, a standard-setting authority would see itself as an idealised rational decision-maker that uses knowledge to seek tirelessly the best possible choices in terms of what is perceived to be theoretically correct options... But standards are invariably determined by the standard-setters' perception of what is practicable, rather than ought to be" (Wallace et al, 1997, p.10). Whilst Australian respondents clearly favoured the direct method, in the UK and USA responses were more equivocal, perhaps persuading the standard-setters to allow choice of method. The preparer support for the indirect method possibly arose from their fixation with the method inherited from the former funds flow statement and from relative savings in the cost and time of preparation (Wallace et al, 1997, p.8).

\section{Reporting Practice When Choice Of Method Is Permitted}

"The decision by standard-setting authorities to permit corporate reporters to choose between the direct and indirect methods must presumably have been underpinned by the expectation that practice would move voluntarily towards the preferred direct method." (Wallace et al, 1997, p.11) This has not occurred. Wallace et al (1997) report a significantly low adoption rate for the direct method over a two-year period (for the UK) ${ }^{27}$, a three-year period (for Canada $)^{28}$ and a four-year period (for the US). The low adoption rate suggests "that when corporate reporters are allowed discretion, they prefer not to change their reporting practices to the one that is perceived as beneficial to end users but considered by them as costly to implement" (Wallace et al, 1997, p.11).

Further evidence of the unpopularity of the direct method of reporting CFO in the United States of America, is provided by the AICPA's annual survey of the financial reports of 600 industrial, merchandising and service corporations. Despite the 'encouragement' by SFAS 95 to use the direct method (AICPA, 1997, p.495), less than 3\% of the 600 companies surveyed used that method: between 1989 (the first full year of the mandatory CFS requirement) and 1996, little change occurred in the number of companies, out of 600, using the direct format for their CFSs (AICPA, 1993, 1997).

\footnotetext{
${ }^{26}$ Despite allowing choice all regulatory authorities suggest that the direct method would provide more helpful information to users than the indirect method (Wallace et al, 1997, p.10).

${ }^{27}$ Wallace et al (1997) examined the 1992 and 1993 annual reports for 320 publicly listed UK firms. Only 4 firms in 1992 (1.25\%) and 8 firms in 1993 (2.5\%) adopted the direct method (p.11). A later study found similar low adoption rates: only 2 out of 200 sampled UK annual reports used the direct method (Wallace et al, 1999).

28 A survey by the Canadian Institute of Chartered Accountants (1995) revealed that of 300 responding firms, only one reported the direct method (Krishnan and Largay, 2000, p.242).
} 


\section{Conclusion}

The quest for harmonisation would suggest that accounting standards should aim to establish a single method of accounting ${ }^{29}$. Yet at present, there would appear to be great difficulty by regulators in setting consistent standards even on a straight-forward item such as the presentation of operating cash flows. The fact that competitors can present information in such different forms, as permitted by allowing a choice between the direct and indirect methods, increases the difficulties involved in inter-firm comparison. And despite the adoption of IAS 7 internationally, it would appear that firms reporting in multiple jurisdictions, and those that prepare consolidated CFS of global operations, may still incur additional costs when reporting CFs if different choices have been made regarding the presentation of OCFs. Users too, when comparing corporate annual reports of firms located in different jurisdictions, will incur additional costs in making such reports comparable (Wallace et al, 1997 p.18-19).

This review of literature and responses to CF exposure drafts suggests that the direct method, by presenting gross receipts and gross expenditures, provides useful supplemental information not readily available with the indirect method: a company's operating cycle can be better understood by providing a comparison between the accrual-based profit and loss statement and the direct method cash flow statement. However, despite the perceived superiority of direct method information, the indirect method has persisted because companies, when given a choice, continue to use the indirect method because it is viewed as being easier and less costly to prepare, and limits disclosure of sensitive information. It is time to restrict this choice - otherwise a potential consequence of adopting international standards could be to perpetuate the current global diversity in cash flow reporting.

\section{References}

1. Accounting Standards Board, (1991), "Cash Flow Statements", Financial Reporting Standard No.1, (September), ASB.

2. Accounting Standards Steering Committee, (1990), "Cash Statements", ED54, (July), ICAEW, London.

3. AICPA, (1993, 1997), Accounting Trends and Techniques, , AICPA, New York.

4. Australian Accounting Standards Board, (1991a), "Statement of Cash Flows", Exposure Draft 52, (May), AARF, Caulfield.

5. Australian Accounting Standards Board, (1991b), "Statement of Cash Flows", Accounting Standard AASB 1026 and Australian Accounting Standard AAS28, (December), AASB, Caulfield.

6. Australian Accounting Standards Board (2002), The Australian Convergence Handbook, Australian Accounting Standards Board, Victoria.

7. Australian Accounting Standards Board (2003), Request for Comment on IAS 7 Cash Flow Statements, Exposure Draft 110, Australian Accounting Standards Board, Victoria.

8. Bahnson, P.R., Miller, P.B.W. and Budge, B.P. (1996), "Nonarticulation in Cash Flow Statements and Implications for Education, Research and Practice", Accounting Horizons, Vol. 10, No. 4, pp.1-15.

9. Canadian Institute of Chartered Accountants, (1985), "Statement of Changes in Financial Position", Accounting Recommendations: General Accounting Section 1540, (September), CICA, Toronto.

10. Carslaw, C., and McNally, Q., (1990), "Statement of Cash Flows - Opportunities for Reappraisal”, Accountants Journal, Vol.69, No.7, (August), p.28 and pp.30-31.

11. Cornell, D.W. and Apostolou, B. (1992), "Direct Approach to Cash Flows enhances Credit Analysis", Business Credit, Vol.94, No.4, pp.10-13.

12. Drtina, R.E. and Largay, J..A. (1985), "Pitfalls in Calculating Cash Flow from Operations", The Accounting Review, Vol.LX, No.2, pp.314-326.

13. Fairfield, P.M., Sweeney, R.J. and Yohn, L.L. (1996), “Accounting Classification and the Predictive Content of Earnings", The Accounting Review, Vol.71, No.3,pp.337-355.

14. Financial Accounting Standards Board, (1978), "Objectives of Financial Reporting by Business Enterprises", SFAC No.1, FASB, Stamford.

15. Financial Accounting Standards Board, (1980a), "Qualitative Characteristics of Accounting Information", SFAC No.2, FASB, Stamford.

\footnotetext{
${ }^{29}$ Except where the peculiarities of a particular business sector necessitate departure from the chosen method.
} 
16. Financial Accounting Standards Board, (1980b), “An Analysis of Issues Related to Reporting Funds Flows, Liquidity and Financial Flexibility”, Discussion Memorandum, (December 15), FASB, Stamford.

17. Financial Accounting Standards Board, (1981), "Reporting Income, Cash Flows, and Financial Position of Business Enterprises", Exposure Draft of a Proposed Statement of Financial Accounting Concepts, (November), FASB, Stamford.

18. Financial Accounting Standards Board, (1984), "Recognition and Measurement in Financial Statements of Business Enterprises", SFAC No.5, FASB, Stamford.

19. Financial Accounting Standards Board, (1986), "Statement of Cash Flows", Exposure Draft, (July), FASB, Stamford.

20. Financial Accounting Standards Board, (1987), “Statement of Cash Flows”, SFAS No.95, (November), FASB, Stamford.

21. Gahlon, J.M. and Vigeland, R.L., (1988), "Early Warning Signs of Bankruptcy using Cash Flow Analysis”, The Journal of Commercial Bank Lending, (December), pp.4-15.

22. Gibson, C.H., Klammer, T.P. and Reed, S.A. (1986), "The Cash Flow Statement", The CPA Journal, November, pp.18-38.

23. Harvey, D., (1991), "Fine Tuning Time (Re ED54)", Certified Accountant, (February), pp.32-33.

24. Heath, L.C., (1978), "Financial Reporting and the Evaluation of Solvency", Accounting Research Monograph 3, American Institute of Certified Public Accountants.

25. Heath, L.C., (1985a), "Let's Scrap the 'Funds' Statement”, in S.A. Zeff and T.K. Keller (eds.), Financial Accounting Theory, 3rd ed., McGraw Hill, New York, pp.241-253.

26. Heath, L.C., (1985b), "Solvency: The Forgotten Half of Financial Reporting", in S.A. Zeff and T.K.Keller (eds.), Financial Accounting Theory, 3rd ed., McGraw Hill, New York, pp.265-274.

27. Hung,H.Y., Chan, M. and Yiu, A. (1995), "The usefulness of Cash Flow Statements", Asian Review of Accounting, Vol.,3 No.1.

28. International Accounting Standards Committee, (1991), "Cash Flow Statements", Proposed International Accounting Standard - Exposure Draft No.36, (July), IASC.

29. International Accounting Standards Committee, (1992), "Cash Flow Statements", International Accounting Standard 7, (December), IASC.

30. Jamieson, B. (1995), The Accounting Jungle, Elsternwick, Vic.: Wrightbooks.

31. Jones, M., (1990), "Decisive Opportunity", Certified Accountant, (December), pp.29-31.

32. Jones, S. and Ratnatunga, J. (1997), "The Decision Usefulness of Cash Flow Statements by Australian Reporting Entities: Some Further Evidence”, British Accounting Review, Vol.29, No. 1, pp.67-85.

33. Jones, S., Romano, C.A. and Smynios, K.X. (1995), "An Evaluation of the Decision Usefulness of Cash Flow Statements by Australian Reporting Entities", Accounting and Business Research, Vol.25, pp.115-129.

34. Klammer, T. and Reed, S.A. (1990), "Operating Cash Flow Formats: Does Format Influence Decisions?" Journal of Accounting and Public Policy, Vol.9, No.3, pp.217-235.

35. Knutson, P.H. (1993), Financial Reporting in the 1990's and Beyond, Association for Investment and Management Research, Charlotteville, VA.

36. Krishnan, G.V. and Largay, J.A. (2000), "The Predictive Ability of Direct Method Cash Flow Information", Journal of Business Finance and Accounting, Vol.27, No.1\&2, pp.215-245.

37. Lee, T.A., (1981a), "Cash Flow Accounting and Corporate Financial Reporting", in M. Bromwich and A. Hopwood (eds), Essays in British Accounting Research, Pitman Publishing, London, pp.63-78.

38. Lee, T.A., (1981b), "Reporting Cash Flows and Net Realisable Values", Accounting and Business Research, (Spring), pp.163-170.

39. Lee, T.A., (1981c), "Cash Flow Accounting and Reporting", in T.A. Lee (ed), Developments in Financial Reporting, Philip Allan, Oxford, pp.148-170.

40. Lee, T., (1982), "Laker Airways - The Cash Flow Truth”, Accountancy, Vol.94, No.1065, (June), pp.115-116.

41. Lee, T.A., (1983), “A Note on Users and Uses of Cash Flow Information”, Accounting and Business Research, Vol.13, No.50, (Spring), pp.103-106.

42. Lee, T.A. (ed.) (1993), Cash Flow Reporting: A Recent History of an Accounting Practice, Garland, London.

43. Mahoney, J.J., Sever, M.V. and Theis, J.A. (1988), "Cash Flow: FASB Opens the Floodgates", Journal of Accountancy, Vol.165, 26-38. 
44. McEnroe, J.E., (1989), "Cash Flow Accounting Revisited: A Note on a Partial Replication of the Lee Study", ABACUS, Vol.25, No.1, (March), pp.56-60.

45. Neill, J.D., Schaefer, T.F., Bahnson, P.R. and Bradbury, M.E., (1991), "The Usefulness of Cash Flow Data: A Review and Synthesis", Journal of Accounting Literature, Vol.10, pp.117-150.

46. New Zealand Society of Accountants, (1987), "Statement of Cash Flows", Statement of Standard Accounting Practice No.10, (October), NZSA.

47. New Zealand Society of Accountants, (1991), "SSAP-10 Revised: Statement of Cash Flows", ED55, NZSA.

48. New Zealand Society of Accountants, (1992), "Statement of Cash Flows", Financial Reporting Standard - 10, (March), NZSA.

49. O’Leary, C.D. (1988), “Cash Flow Reporting, Part 1: An Overview of SFAS 95”, Journal of Commercial Bank Lending, May, pp.22-28.

50. Pratt, J. and Chrisman, H.H. (1982), "Teaching the Statement of Changes in Financial position: An Empirical Study", The Accounting Review, Vol.LVII, No.4, pp.794-805.

51. Trout, R.K., Tanner, M.M. and Nicholas, L. (1993), "On Track with Direct Cash Flow", Management Accounting, Vol.75, No.1, pp.23-27.

52. Seed, A.H., (1984), “The Funds Statement: How can it be Improved?", Financial Executive, Vol.52, No.10, (October), pp.52-55.

53. Smith, G.R. and Freeman, R.J. (1996), "Statement of Cash Flows: The Direct vs. Indirect Method Debate Continues", Government Finance Review, Vol.12, pp.17-21.

54. Sorter, G.H., (1982), "The Emphasis on Cash and Its Impact on the Funds Statement - Sense and Nonsense", Journal of Accounting, Auditing and Finance, Vol.5, No.3, (Spring), pp.188-194.

55. Thompson, J.H. and Buttross, T.E. (1988), "Return to Cash Flow", The CPA Journal, Vol.58, No.3, pp.30-40.

56. Wallace, R.S. and Collier P.A, (1991), "The 'Cash' in Cash Flow Statements: A Multi-Country Comparison". Accounting Horizons, Vol. 5, No.4, pp.44-52.

57. Wallace, R.S.O., Choudhury, M.S.I. and Pendlebury, M. (1997), Cash Flow Statements: An International Comparison of Regulatory Positions, The International Journal of Accounting, Vol.32, No. 1, pp.1-22.

58. Wallace, R.S.O., Choudhury, M.S.I. and Adhikari, A. (1999), "The Comprehensiveness of Cash Flow reporting in the United Kingdom: Some Characteristics and Firm-Specific Determinants, The International Journal of Accounting, Vol.34, No.3, pp.311-347.

59. Ward, T. (1995), "Using Information from the Statement of Cash Flows to Predict Insolvency", Journal of Commercial Bank Lending, Vol.77, No.7, pp.29-36.

60. White,G.I., Sondhi, A.C. and Fried. D. (1998), The Analysis and Use of Financial Statements, New York: John Wiley and Sons Inc.

61. Yap, C. (1997), "Users' Perceptions of the Need for Cash Flow Statements-Australian Evidence", The European Accounting Review, Vol.6, No. 4, pp.653-672. 